\title{
Quality Evaluation of Swallow Meal Produced from Blends of Acha, Fluted Pumpkin Seed and Soybean Flours
}

\author{
${ }^{1}$ Okechukwu-Ezike, N.C and ${ }^{2}$ Oly-Alawuba, N.M \\ ${ }^{1}$ Department of food science and technology, Imo State University Owerri. \\ ${ }^{2}$ Department of Nutrition and Dietetics, Imo State University, Owerri.
}

\begin{abstract}
The proximate and functional properties of the composite flours of Acha, fluted pumpkin seed and soybean (AFS) were determined in order to evaluate the quality of the swallow meal. The dried seeds and grains were milled into fine flour particles and blended to produced composite flours in 3 different ratios (AFS); 70:10:20\%, 60:20:20\% and 40:20:40\%. The proximate composition result showed protein enriched flours. The results of the functional properties were as follows: bulk density ranged from $0.40 \mathrm{~g} / \mathrm{ml}$ to $0.599 / \mathrm{ml}$, water absorption capacity $1.04 \mathrm{~g} / \mathrm{g}-1.19 \mathrm{~g} / \mathrm{g}$, oil absorption capacity $0.53 \mathrm{~g} / \mathrm{g}-1.48 \mathrm{~g} / \mathrm{g}$ and swelling index $53.78 \mathrm{~g} / \mathrm{g}-83.45 \mathrm{~g} / \mathrm{g}$. The mean values for the functional properties further showed that the flours can be used extensively in various dietary preparations. The reconstituted Swallow meals were evaluated for their nutrient quality. The results were as follows; moisture content: $20.95-25.59 \%$, protein: $14.69-18.76 \%$, fibre: $1.85-1.92 \%$, Ash: $2.15-2.68 \%$, fat: $2.03-2.50 \%$ and carbohydrate $49.00-57.03 \%$.
\end{abstract}

Keywords: Acha, Fluted pumpkin seeds, soybean, composite flours (AFS), proximate composition, functional properties.

DOI: $10.7176 / \mathrm{FSQM} / 92-08$

Publication date: December $31^{\text {st }} 2019$

\section{0: Introduction}

Eating good food can define our life in the wake of various illness and various health problems such as cancer, diabetes, etc. It is important for people to carefully watch what they eat and the rate at which such foods are consumed (Becky, 2017). Excessive consumption of certain types of foods is capable of causing health risks. Diets that are carbohydrate dense could adversely affect glucose metabolism in the body, increasing the risk of diabetes.

Swallow meal is a popular food in Nigeria. It is so described because rather than chewing, it is just swallowed after dipping in a soup. It is one of the popular traditional foods in Nigeria. Swallow meals in Nigeria are usually starchy as they are very high in carbohydrate and eaten with different kinds of soups (Becky, 2017).

This popular traditional food varies from place to place, cassava products (Garri, fufu), pounded yam are indigenous to the eastern part of Nigeria, amala to the western part of Nigeria, Tuwo Shinkafa is majorly consumed in the Northern Part of Nigeria (Quora, 2017). Other such foods include wheat (Semolina, whole wheat swallow), oatmeal swallow, millet swallow and starch.

Many studies have also shown that eating a diet rich in carbohydrate in linked to a higher risk of type two diabetes, heart diseases, stroke and weight gain (Ryan, 2017). The glycemic index of swallow meals are considered because they affect blood glucose levels. Carbohydrates with low glycemic values are more slowly digested, absorbed and metabolized and cause a lower and slower rise in blood glucose, which is advised for prediabetic and diabetic individuals. According to Omoregie and Osagie (2008), the glycemic index of some of our swallow meals are $98.60 \pm 2.68$ Starch (Cassava), $82.25 \pm 0.05$ eba (Cassava), $84.35 \pm 2.68$ Amala (Yam), 86.8 \pm 0.5 Tuwo masara (Maize), $93.60 \pm 2.25$ Tuwo gero (Millet), $85.30 \pm 1.05$ Tuwo dawa (Sorghum), $95.30 \pm 1.25$ Tuwo Shinkafa (Rice), $95.28 \pm 0.04$ Semolina (Wheat), while acha has a glycemic index of 45 and 35 in type two diabetic patients and healthy subjects respectively (Janet et al; 2011). 
Acha grain is considered a rich source of minerals, vitamins, fiber, protein, carbohydrate and amino acid. It contains cysteine and methionine, it is good for cardiovascular function diabetes and an excellent meal for weight loss compared to most cereals (Istifamus and Agbo, 2016).

Fluted pumpkin seeds have nutritive and calorific value which makes it a good source of protein, edible oils and fat (Adenike et al., 2014). It has the ability to ease some health conditions like protecting the liver and treating arthritis, prevent prostate in men, aids hypertension treatment and also protects against osteoporosis (Blessing, 2015).

Soybean is a good source of protein for diabetic patients. It also offers great nutritional value containing no cholesterol. Low amounts of saturated fats and good level of fiber, zinc, iron and calcium (Cleveland and Clinic, 2019). It is economically the most important bean in the world, providing vegetable protein for millions of people and ingredients for hundred of chemical products (Britannica, 2019).

The swallow meal forms most of the daily meals of Nigeria, especially the South Eastern part. Swallow meals from cassava and wheat based products are low in nutrient, containing mostly carbohydrates. People are beginning to avoid it for the quest of living healthy as there is an increasing rate of diabetes, obesity and other weight related diseases.

There is need for the fortification of our traditional swallow meal is mostly low in protein, micronutrients and high in carbohydrate. This fortification will prevent development of certain diseases and health disorders resulting from high carbohydrate consumption. The utilization of locally available nutritious seeds ensure food security and sustainability. These composite flours can also make for versat in thile applications in the production of some foods, like in baking and production of complementary foods.

\section{0: Materials and Methods}

The Acha grain, fluted pumpkin seed and soybean used were bought from Ekeukwu Owerre Market, Imo State. They were processed in the Food Science and Technology laboratory, Imo State University, Owerri.

\section{Production of Acha flour}

Cream coloured Acha grains (1.5kg) were washed with clean water to separate stone, sand and other contaminants, then dried in the cabinet dryer at $70^{\circ} \mathrm{C}$ for 3 hours. The dried acha grains were milled into flour using a commercial hammer mill and sieved with $0.2 \mathrm{~mm}$ screen size.

\section{Production of Fluted Pumpkin Seed Flour}

Fluted pumpkin seeds $(1 \mathrm{~kg})$ were extracted from the fruit gourds, the extracted seeds were deshelled, cleaned and freed from foreign materials. The seeds were shredded and dried in a cabinet dryer at $70^{\circ} \mathrm{C}$ for 1 hour. The dried seeds were milled with commercial grinder and sieved through $0.2 \mathrm{~mm}$ screen size.

\section{Production of Soybean Flour}

Soybean seeds $(1 \mathrm{~kg})$ were sorted to remove pebbles, stones and other extraneous materials. They were washed and steeped for 10 hours. The steeped soybean seeds were drained and precooked for 15 minutes at $100^{\circ} \mathrm{C}$ after which they were manually dehulled (by rubbing in between the palms) and the hulls were removed by flushing with clean water. The dehulled soybean seeds were dried in the cabinet dryer at $70^{\circ} \mathrm{C}$ for 4 hours and dry milled into flour. The flour was sieved using a sieve of $0.2 \mathrm{~mm}$ screen size to obtain soy flour. 


\section{Flour Blending Ratio}

Table 2.1: shows the flour blending ratios into different percentage

\begin{tabular}{|c|c|c|}
\hline Acha Flour (\%) & Fluted pumpkin seed flour (\%) & Soybean flour (\%) \\
100 & - & - \\
- & 100 & 100 \\
70 & - & 20 \\
60 & 10 & 20 \\
40 & 20 & 40 \\
\hline
\end{tabular}

\section{Preparation of the Swallow Meal}

All the products were prepared using the formulated flour blends according to the following procedure: $300 \mathrm{~g}$ of the flour was poured gradually into the pot containing $100 \mathrm{ml}$ of hot water $\left(100^{\circ} \mathrm{C}\right)$ and stirred continuously. This was done until it became smooth and hard, then more $200 \mathrm{ml}$ hot water was poured in and allowed to boil for a minute to cook.

\section{Quality Analysis: Proximate Composition Determination}

The standard analytical procedures employed for the proximate analysis determination of the samples were according to the techniques described by Onwuka (2005).

\section{Moisture Content Determination}

The petri dishes were washed thoroughly, dried in the oven and put inside the dessicator to cool. The weight of each dish was taken. About $5 \mathrm{~g}$ of the food samples was added to each petri dish and their weights were taken. The samples were dried in the moisture oven at $105^{\circ} \mathrm{C}$ for 2 hours until a constant weight were obtained. The samples were dried in the deisscator and the dry weight of samples plus dish were taken.

\section{Ash Content Determination}

The samples (5g each) were added into porcelain crucibles previously weighed, and ash to dryness in a muffle furnace at $500^{\circ} \mathrm{C}$ for 2 hours until a white or light gray ash appeared. The samples were cooled in a dessicator and reweighed.

\section{Crude Fiber Determination}

About $2 \mathrm{~g}$ of the samples were defatted with petroleum ether, and were boiled under reflux for 30 minutes with $200 \mathrm{ml}$ of a solution containing $1.25 \mathrm{~g} \mathrm{H}_{2} \mathrm{SO}_{4}$ per $100 \mathrm{ml}$ of solution. The solution was filtered thoroughly with cheese cloth on a filtered funnel. The samples were washed with boiling water, until they are no longer acidic. The residues were transferred into a beaker and boiled for 30 minutes with $200 \mathrm{ml}$. The final residue of the samples was filtered through a thin but closed pod of washed and ignited asbestors in a gooch crucible. They were dried in an electric oven and weighed. They were further incinerated in muffle furnace, cooled and reweighed.

\section{Fat Content Determination}

Boiling flasks $(250 \mathrm{ml})$ were dried at $105^{\circ} \mathrm{C}$ for about 30 minutes and were transferred into a dessicator to cool. About $2 \mathrm{~g}$ of samples were weighed accurately into a labeled thimbles. The boiling flasks were filled with about $200 \mathrm{ml}$ of petroleum ether and the extraction thimbles were plugged lightly with cotton wool. The soxhlet apparatus was assembled and allowed to reflux for about 6hours. The thimble was removed with care and petroleum ether was collected in the top container of the set up and drained into a container for re-use. The flask was removed when it was almost free of petroleum ether and was dried at $105^{\circ} \mathrm{C}$ per 1 hour. The flask was transferred to a dessicator to cool and was reweighed. 


\section{Protein Content Determination}

The samples $(2 \mathrm{~g})$ were weighed into a Kjeldahl flask and about $2 \mathrm{~g}$ of copper sulphate and $6 \mathrm{~g}$ of sodium sulphate were added. $20 \mathrm{ml}$ of concentrated sulphuric acid and the mixture were occasionally shaked until the substance dissolved. The content of the flask was heated unitl the solution turned green. The samples were cooled and transferred to the distillation apparatus, $5 \mathrm{ml}$ boric acid and 3 drops of methyl red in a $50 \mathrm{ml}$ graduates conical flask and start to distillate. After distillation, it was titrated with $0.1 \mathrm{~N} \mathrm{H}_{2} \mathrm{SO}_{4}$ acid. The nitrogen and protein content were calculated.

\section{Carbohydrate Content Determination}

It was obtained by adding all estimates of the other fractions of the proximate parameters and substracting from 100.

\section{Functional Properties Determination}

The standard analytical procedures employed for the determination of functional properties of the samples were according to the techniques stipulated by Onwuka (2005).

\section{Bulk Density}

A graduated cylinder $10 \mathrm{ml}$ was weighed dry and gently filled with flour samples. The bottom of the cylinder was tapped on a surface gently, until there is no further diminution of the sample level after filling to the $10 \mathrm{ml}$ mark. It was then weighed.

\section{Water Absorption Capacity}

About $1 \mathrm{~g}$ of the sample was weighed into a conical graduated centrifuge tube, about $10 \mathrm{ml}$ distilled water was added to mix the sample for 30 seconds. The sample was allowed to stand for 30 minutes at room temperature and then centrifuged at 5000xg for 30minutes. After this, the volume of the free water (supernatant) was read.

\section{Swelling Capacity}

The swelling capacity was determined using a method described by Ukpabi and Ndimele (1990). Ig of each sample was weighed into a dry $100 \mathrm{ml}$ measuring cylinder, and distilled water was added to the $100 \mathrm{ml}$ mark and allowed to stand for 24 hours.

\section{0: Results and Discussion}

Table 1 shows the proximate composition of the flour samples. The moisture content of the flour blends ranged from 5.30 to $7.56 \%$. The value obtained was within the acceptable moisture level of dried powder (14 or less NDSU, 2018). This shows that the flour samples can be stored at room temperature for a long period without being attacked by microorganisms (Bolarinwa et al., 2015) or insect and does not permit cakuring of flour. The more moisture of food contained, the more likelihood of spoilage (Nzelu et al., 2012).

The protein content of the flour blend samples increased with increased in fluted pumpkin seed and soybean content. Protein is essential for growth, repair of the body and maintenance of good health. It ranged from $7.44 \%$ to $21.72 \%$.

The crude fiber content of the flour blends ranged from 2.18 to $6.16 \%$. The fiber content increased with increase in fluted pumpkin seed. Crude fiber is known to lower total and low density lipoprotein (LDL) cholesterol which may reduce the risk of cardiovascular disease, adds bulk to the food volume providing satiety without increasing caloric content. It also aids the human digestive system (Wikipedia, 2019).

The ash content of the flour blends ranged from $1.96 \%$ to $3.86 \%$. Ash content represents the total mineral content of a food (Discover foodtech, 2019). Mineral content is a vital component in food nutrition.

The fat content of the flour blend samples ranged from $3.07 \%$ to $5.30 \%$. it is important for humans because it permits the possible storage energy in the smallest possible amount of food substance (Sciencedirect. 2015). 
Levels of fat obtained from the flour blends are not very high to cause rancidity in the flour which can cause development of unpleasant and odorous compounds.

The carbohydrate content of the flour blend ranged from $59.4 \%$ to $70.92 \%$. the values revealed that, the samples are good sources of energy.

Table 1: Proximate Composition of Flour Blend Samples

\begin{tabular}{|c|c|c|c|c|c|c|}
\hline Sample & $\begin{array}{l}\text { Moisture } \\
(\%)\end{array}$ & Protein (\%) & $\begin{array}{c}\text { Crude Fiber } \\
(\%)\end{array}$ & $\operatorname{Ash}(\%)$ & Fat $(\%)$ & Carbohydrate (\%) \\
\hline A & $5.96^{\mathrm{b}} \pm 0.02$ & $7.44^{c} \pm 0.44$ & $3.34^{b} \pm 0.05$ & $1.96^{\mathrm{c}} \pm 0.02$ & $4.37^{\mathrm{b}} \pm 0.04$ & $70.92^{\mathrm{a}} \pm 0.45$ \\
\hline B & $5.30^{\mathrm{b}} \pm 0.42$ & $21.72^{\mathrm{a}} \pm 0.21$ & $6.16^{\mathrm{a}} \pm 0.05$ & $1.97^{\mathrm{c}} \pm 0.01$ & $5.20^{\mathrm{ab}} \pm 0.28$ & $59.74^{\mathrm{a}} \pm 0.59$ \\
\hline $\mathrm{C}$ & $7.56^{\mathrm{b}} \pm 0.02$ & $20.31^{\mathrm{a}} \pm 0.44$ & $3.72 \pm 0.02$ & $2.98^{c} \pm 0.02$ & $4.56^{\mathrm{ab}} \pm 0.05$ & $60.86^{a} \pm 0.53$ \\
\hline $\mathrm{D}$ & $5.87^{b} \pm 0.09$ & $16.41^{\mathrm{b}} \pm 0.21$ & $2.18^{\mathrm{d}} \pm 0.02$ & $2.56^{\mathrm{d}} \pm 0.02$ & $3.07^{\mathrm{d}} \pm 0.09$ & $69.91^{\mathrm{a}} \pm 0.23$ \\
\hline E & $5.55^{b} \pm 0.42$ & $17.66 \pm 0.21$ & $2.85^{\mathrm{c}} \pm 0.15$ & $3.17^{b} \pm 0.04$ & $3.97^{\mathrm{c}} \pm 0.04$ & $64.82^{\mathrm{a}} \pm 3.20$ \\
\hline $\mathrm{F}$ & $5.60^{\mathrm{b}} \pm 0.14$ & $20.94^{\mathrm{a}} \pm 1.32$ & $2.34^{\mathrm{d}} \pm 0.25$ & $3.86^{\mathrm{a}} \pm 0.08$ & $5.30^{\mathrm{a}} \pm 0.42$ & $62.12^{\mathrm{a}} \pm 4.58$ \\
\hline LSD & 0.18850 & 0.61772 & 0.12692 & 0.04397 & 0.21471 & 0.5664 \\
\hline
\end{tabular}

Mean values within the same superscript along the column are not significantly different $(\mathrm{p}<0.05)$.

Keywords

Sample A $\quad$ - $\quad$ Acha Flour (100\%)

Sample B $\quad$ - $\quad$ Fluted Pumpkin flour (100\%)

Sample C $\quad$ - $\quad$ Soybean flour (100\%)

Sample D $\quad$ - $\quad$ Acha flour, fluted pumpkin flour and soybean flour (700:10:20)

Sample E $\quad$ - $\quad$ Acha flour, fluted pumpkin flour and soybean flour $(60: 20: 20)$

Sample F $\quad$ - $\quad$ Acha flour, fluted pumpkin flour and soybean flour (40:20:40)

Table 2 shows the functional properties of the flour blends. The bulk density values obtained from the flour blends ranged from $0.40 \mathrm{~g} / \mathrm{ml}$ to $0.50 \mathrm{~g} / \mathrm{ml}$. The result revealed low bulk density values which favors the compactness of high volume of food intake indicating more nutrient intake and better nutrition.

Values obtained from the water absorption capacity ranges from $1.04 \mathrm{~g} / \mathrm{g}$ to $1.19 \mathrm{~g} / \mathrm{g}$ and the oil absorption capacity ranged from $0.53 \mathrm{~g} / \mathrm{g}$ to $1.48 \mathrm{~g} / \mathrm{g}$. water and oil absorption capacity of food are affected by the intrinsic factors of food protein; amino acid composition, protein conformation and surface polarity or hydrophobicity (Suresh and Smasher, 2013). Interactions of water and oil with flour are very importat in food systems because of their effects on the flavor and texture of foods (Olorode, et al., 2014).

Swelling index evaluation ranged from $53.78 \%$ to $83.45 \%$. swelling capacity depends on the size of the particles, type, variety and type of process methods of the flour (Suresh et al., 2015). The swelling capacity of the blends increased with soybean and fluted pumpkin seed flour. High swelling capacity is beneficial in food baking systems.

Table 2: Functional Properties of the Flour Samples

\begin{tabular}{|l|l|l|l|l|}
\hline $\begin{array}{l}\text { Samples } \\
\text { /Parameters }\end{array}$ & \multicolumn{1}{|c|}{$\begin{array}{c}\text { Bulk Density } \\
(\mathbf{g} / \mathbf{m l})\end{array}$} & Oil Absorption $\mathbf{( g / g )}$ & $\begin{array}{c}\text { Water Absorption } \\
(\mathbf{g} / \mathbf{g})\end{array}$ & $\begin{array}{c}\text { Swelling Capacity } \\
\mathbf{( g / g )}\end{array}$ \\
A & $0.55^{\mathrm{b}} \pm 0.07$ & $0.53^{\mathrm{a}} \pm 0.60$ & $1.17^{\mathrm{a}} \pm 0.007$ & $83.45^{\mathrm{a}} \pm 0.64$ \\
$\mathrm{~B}$ & $0.50^{\mathrm{c}} \pm 0.00$ & $1.129^{\mathrm{a}} \pm 0.00$ & $1.04^{\mathrm{b}} \pm 0.05$ & $71.95^{\mathrm{c}} \pm 0.06$ \\
$\mathrm{C}$ & $0.59^{\mathrm{a}} \pm 0.007$ & $1.38^{\mathrm{a}} \pm 0.000$ & $1.11^{\mathrm{ab}} \pm 0.007$ & $76.09^{\mathrm{b}} \pm 0.007$ \\
$\mathrm{D}$ & $0.43^{\mathrm{d}} \pm 0.007$ & $1.29^{\mathrm{a}} \pm 0.007$ & $1.15^{\mathrm{a}} \pm 0.007$ & $53.78^{\mathrm{f}} \pm 0.02$ \\
$\mathrm{E}$ & $0.48^{\mathrm{c}} \pm 0.00$ & $1.15^{\mathrm{a}} \pm 0.007$ & $1.19^{\mathrm{a}} \pm 0.14$ & $69.60^{\mathrm{d}} \pm 0.01$ \\
$\mathrm{~F}$ & $0.40^{\mathrm{d}} \pm 0.007$ & $1.48^{\mathrm{a}} \pm 0.001$ & $1.18^{\mathrm{a}} \pm 0.007$ & $60.98^{\mathrm{e}} \pm 0.72$ \\
& & & & \\
LSD & 0.00577 & 0.24836 & 0.02449 & 0.39783 \\
\hline
\end{tabular}

Mean values within the same superscript along the column are not significantly different $(\mathrm{p}<0.05)$ 
Keywords

Sample A

Sample B

Sample C

Sample D

Sample E

Sample F

$\begin{array}{ll}- & \text { Acha Flour }(100 \%) \\ - & \text { Fluted pumpkin seed flour (100\%) (FPSF) } \\ - & \text { Soybean flour }(100 \%) \\ \text { - } & \text { Acha + FPS Flour +Soybean flour (70:10:20\%) } \\ - & \text { Acha flour + FPS flour + Soybean flour }(60: 20: 20 \%) \\ - & \text { Acha flour + FPS flour + Soybean flour }(40: 20: 40 \%)\end{array}$

Table 3 shows the proximate composition of the swallow meal from the flour samples. The moisture content of the swallow meals ranged from $20.95 \%$ to $27.97 \%$. The moisture content increase was as a result of water addition during the swallow meal processing. This increased moisture content gives the swallow meal a smooth texture and good moldability. Values obtained from the protein analysis ranged from $3.47 \%$ to $19.03 \%$. a slight decrease in protein levels well observed in the sample samples, this could be as a result of water dilution or heat during processing.

Crude fiber values obtained ranged from $1.56 \%$ to $1.92 \%$. Decrease in crude fiber levels were recorded, which could be as a result of heat during processing or dilution. Result of the ash content ranged from $1.15 \%$ to $2.68 \%$. The slight decrease of the ash content of the swallow meal could be as a result of leaching of the minerals into the boiling water during preparation and heat during preparation. The recorded fat content of the swallow meals ranged from $0.67 \%$ to $2.52 \%$. This decrease in the swallow meals could be attributed to the effect of heat used during preparation.

Carbohydrate content of the swallow meals ranged from $48.75 \%$ to $66.77 \%$. Decrease in the carbohydrate content was also observed compared to carbohydrate content of the flour.

Table 3: Proximate Composition of the Swallow Meals

\begin{tabular}{|lllllll|}
\hline Sample & Moisture (\%) & \multicolumn{1}{c}{ Protein (\%) } & $\begin{array}{c}\text { Crude Fiber } \\
(\%)\end{array}$ & $\begin{array}{c}\text { Ash (\%) } \\
\text { Foat (\%) }\end{array}$ & Carbohydrate (\%) \\
A & $26.37^{\mathrm{b}} \pm 0.04$ & $3.47 \pm 0.04$ & $1.56^{\mathrm{b}} \pm 0.02$ & $1.15^{\mathrm{c}} \pm 0.04$ & $0.67^{\mathrm{c}} \pm 0.09$ & $26.77^{\mathrm{a}} \pm 0.03$ \\
$\mathrm{~B}$ & $27.96^{\mathrm{a}} \pm 0.05$ & $15.61^{\mathrm{b}} \pm 0.02$ & $1.90^{\mathrm{a}} \pm 0.02$ & $1.84^{\mathrm{b}} \pm 0.00$ & $2.37^{\mathrm{a}} \pm 0.04$ & $50.43^{\mathrm{d}} \pm 0.22$ \\
$\mathrm{C}$ & $25.96^{\mathrm{c}} \pm 0.02$ & $19.03 \mathrm{a} \pm 0.05$ & $1.80^{\mathrm{ab}} \pm 0.00$ & $1.80^{\mathrm{ab}} \pm 0.00$ & $2.52^{\mathrm{a}} \pm 0.10$ & $48.75^{\mathrm{e}} \pm 0.22$ \\
$\mathrm{D}$ & $25.59^{\mathrm{d}} \pm 0.01$ & $14.69^{\mathrm{c}} \pm 0.44$ & $1.92^{\mathrm{a}} \pm 0.11$ & $2.12^{\mathrm{ab}^{\mathrm{b}} \pm 0.02}$ & $2.03^{\mathrm{b}} \pm 0.02$ & $53.64^{\mathrm{c}} \pm 0.60$ \\
$\mathrm{E}$ & $20.95^{\mathrm{f}} \pm 0.04$ & $15.56 \mathrm{~b} \pm 0.04$ & $1.85^{\mathrm{ab}} \pm 0.15$ & $2.32^{\mathrm{ab}^{\mathrm{b}} \pm 0.32}$ & $2.34^{\mathrm{a}} \pm 0.02$ & $57.03^{\mathrm{b}} \pm 0.12$ \\
F & $25.16^{\mathrm{e}} \pm 0.05$ & $18.76^{\mathrm{a}} \pm 0.007$ & $1.89^{\mathrm{a}} \pm 0.01$ & $2.68^{\mathrm{a}} \pm 0.04$ & $2.50^{\mathrm{a}} \pm 0.007$ & $49.00 \pm 0.12$ \\
LSD & 0.04282 & 0.18547 & 0.08042 & 0.14227 & 0.06390 & 0.0567 \\
\hline
\end{tabular}

Mean values within the same superscript along the column are not significantly different $(\mathrm{p}<0.05)$.

Keywords

Sample A

Sample B

Sample C

Sample D

Sample E

Sample F

$\begin{array}{ll}- & \text { Acha flour }(100 \%) \\ - & \text { Fluted pumpkin seed (FPS) Flour }(100 \%) \\ - & \text { Soybean }(100 \%) \\ - & \text { Acha + FPS Flour +Soybean flour }(70: 10: 20 \%) \\ - & \text { Acha flour + FPS flour + Soybean flour }(60: 20: 20 \%) \\ - & \text { Acha flour + FPS flour + Soybean flour }(40: 20: 40 \%)\end{array}$

Table 4 shows the sensory attributes of the swallow meals

The moldability values ranged from 2.43 to 7.60 . The results showed higher moldability in samples containing Acha flour. Moldability is an important parameter in assessing swallow meals, thus, higher moldability, higher consumer acceptability.

The aroma of the swallow meals ranged from 4.20 to 6.83 . Aroma plays a central role in our perception of food. This sense explores our food before we eat. Appearance of the swallow samples were evaluated, results obtained ranged from 5.23 to 7.20. appearance is a very important attribute of food, this feature has a psychological effect on consumers. When the appearance of a food is appealing they tend to eat well.

The texture results of the swallow samples ranged from 2.50 to 7.90 . the food texture is important in the enjoyment and acceptability of the food products. The general acceptability results obtained from the swallow 
meals ranged from 3.63 to 7.90 . The result revealed that Sample F had appreciable moldability, texture, appearance and aroma values.

Table 4.4: Sensory Attributes of the Swallow Meals

\begin{tabular}{|c|c|c|c|c|c|}
\hline $\begin{array}{l}\text { Samples } \\
\text { /Parameters }\end{array}$ & Moldability & Aroma & Appearance & Texture & $\begin{array}{c}\text { General } \\
\text { acceptability }\end{array}$ \\
\hline A & $6.96^{\mathrm{a}} \pm 1.29$ & $5.53^{\mathrm{c}} \pm 1.22$ & $6.13^{\mathrm{bc}} \pm 1.07$ & $7.43^{\mathrm{a}} \pm 0.85$ & $6.93^{\mathrm{b}} \pm 0.82$ \\
\hline $\mathrm{B}$ & $2.43^{\mathrm{c}} \pm 1.30$ & $5.83^{b c} \pm 1.78$ & $5.23^{\mathrm{c}} \pm 1.77$ & $2.50^{c} \pm 1.59$ & $3.63^{\mathrm{d}} \pm 1.51$ \\
\hline $\mathrm{C}$ & $5.26^{\mathrm{b}} \pm 1.52$ & $4.20^{\mathrm{d}} \pm 1.15$ & $6.26^{\mathrm{ab}} \pm 1.04$ & $6.16^{b} \pm 1.08$ & $5.83^{c} \pm 0.83$ \\
\hline $\mathrm{D}$ & $7.73 \pm 0.73$ & $6.83 \pm 1.01$ & $6.86^{\mathrm{ab}} \pm 0.93$ & $7.53^{\mathrm{a}} \pm 0.86$ & $7.36^{\mathrm{ab}} \pm 0.92$ \\
\hline $\mathrm{E}$ & $7.20 \pm 1.32$ & $6.50 \pm 1.22$ & $6.66^{\mathrm{ab}} \pm 1.15$ & $7.53^{\mathrm{a}} \pm 0.86$ & $7.33^{\mathrm{ab}_{ \pm}} \pm 0.92$ \\
\hline $\mathrm{F}$ & $7.60^{\mathrm{a}} \pm 0.85$ & $6.73^{\mathrm{ab}^{\mathrm{b}}} \pm 1.48$ & $7.20^{\mathrm{a}} \pm 1.12$ & $7.90^{\mathrm{a}} \pm 1.12$ & $7.90^{\mathrm{a}} \pm 0.95$ \\
\hline LSD & 0.31200 & 0.34573 & 0.33081 & 0.28275 & 0.25471 \\
\hline
\end{tabular}

Mean values within the same superscript along the column are not significantly different $(\mathrm{p}<0.05)$.

Sample A $\quad$ - $\quad$ Acha flour (100\%)

Sample B $\quad$ - $\quad$ Fluted pumpkin seed (FPS) flour (100\%)

Sample C $\quad$ - $\quad$ Soybean flour (100\%)

Sample D $\quad$ - $\quad$ Acha + FPS Flour +Soybean flour (70:10:20\%)

Sample E $\quad$ - $\quad$ Acha flour + FPS flour + Soybean flour $(60: 20: 20 \%)$

Sample F $\quad-\quad$ Acha flour + FPS flour + Soybean flour $(40: 20: 40 \%)$

\section{Conclusion}

This study have proved that these nutrient rich swallow products produced from the flour blends of Acha, fluted pumpkin seed and soybean flour will be able to replace the consumption of carbohydrate densed swallow meals which with constant consumption cause obesity, type 2 diabetes and other cardiovascular diseases. The functional properties of the flour blends have also shown potentials of the flours in industrial applications especially in the formulations of complementary food thus creating more value addition. The sensory attributes of the swallow meals revealed high acceptability of samples containing acha samples D, E and F with Sample F being the most acceptance.

The study also revealed that high protein (16-20\%) protein and mineral enriched flours and swallow meals could be produced from Acha, fluted pumpkin seed and soybean flour blends.

\section{REFERENCES}

Becky Onoise (2017). 11 swallows and their health benefit. https://connectnigeria.com/articles/2017/07/top-11swallows-in-Nigeria. Accessed on 29th March.

Blessing Opara (2015). Benefits of fluted pumpkin seed (telfaira occidentalis). https://www.global.food.book.com

Britannica (2019). Soybean. https://www.britannica.com/plant/soybean. accessed on 15th March.

Discover Food Tech (2019). Bioanalytical and ADME laboratory services. Estimation of Ash Content in Foods. https://www.google.com/amp/

Istifanus, M. F and Agbo, E. A (2016). Nutritional and health benefits of Acha (Digitaria exilis) in the human diet; A Review. Nigerian Food Journal 34(2).

Janet, O. Alegbejo, Ameh, O. A, William Ogala, and Salisu Ibrahim (2011). Glycemic Index of Acha (Fonio) in healthy and diabetic subject. Journal of Pure and applied microbiology 5(1):117-122.

N.D.S.U (North Dakota State University) (2018). Wheat quality and carbohydrate research. https://www.ndsu.edu/faculty/simsek. accessed on 12/10.

Nzelu, L. C, Nwosu, U. L and Onwurah, C. O. (2012). Food Analysis: Principles and Practice. Enugu: Fergu Nwankwo Printing service. 
Olorode, O. O., Idowu, M. A., Bamgbose, A and Ayano, A. E (2014). Chemical, phytochemical and functional properties of selected seed flours. International journal of nutrition and food science 3(6): 572-578.

Omoregie, E. S and Osagie, A. U (2018). Glycemic index and glycemic load of some Nigerian foods. Pakistan journal of nutrition 7(5):710-716.

Onwuka, G. I (2005). Food Analysis and Instrumentation theory and practice. Naphtali Prints, Lagos, Nigeria.

Quora (2017). What are the most popular Nigerian swallows. https:www.quora.com/what-are-the-most-popularNigerian-swallows. Accessed on 16/03/2019.

Ryan Raman (2017). 19 Foods that are high in starch. https:/www.healthline.com/nutrition/high-starch-foods. Accessed on 21/03/.

Science Direct (2013). Fats and Oil handbook. https://www.sciencedirect/article/bii/com Accessed on $\underline{12 / 03 / 2019}$.

Suresh C. Samsher, Singh and Durvesh, K. (2015). Evaluation of functional properties of composite flours and sensory attributes of composite flour biscuits. Journal of food science technology, 52(6) 3681-3688.

Suresh Chandra and Samsher Singh (2013). Assessment of functional properties of different flours. African journal of agricultural research 8(38): 4849-4852.

Ukpabi, U. and Ndimele, C. (1990). Evaluation of the quality of grain produced in Imo State. Nigerian Food journal 8(1):105-109.

Wikipedia, (2019). Dietary fiber. https://en.wikipedia.org/wiki.dietaryfibre. 